\title{
Grant Code Sanctions of Polri Members Who Have Disconnected The Court Binding Drug Abuse (Case Study Polres Cirebon)
}

\author{
Joseph Diko Reinol Panjaitan ${ }^{1}$
}

\begin{abstract}
This study aims to identify and understand the sanctions in the Code of Conduct Police officers and efforts to the implementation of sanctions against Alleged offenders alleged to have violated the code of Professional Ethics of Police, in the form of deeds has committed the crime of Abuse of Narcotics kind Sabu-shabu and cases criminal has received the Decision of the Court Of Sumber country, with an excerpt of Decision No. 394 / Pid.Sus / 2017 / PN.Sbr. October 19, 2017, which states the defendant initials S, proven legally and convincingly guilty of committing the crime of abuse of Narcotics Group I For Yourself and sentenced to imprisonment for six (6) months. This research was conducted in Cirebon. To the authors conducted a study with the title "Provision of the Code sanctions Police Members Who Have Strength Disconnect Law Courts Stay In Drug Abuse". If a member of the National Police of an offense or crime, the police members will litigants and undergo a criminal justice process for members of the Indonesian National Police is generally done according to the law applicable in the general court.

Keywords: Police; Narcotics; Police Professional Code of Conduct of Police.
\end{abstract}

\section{Introduction}

Police of Republic of Indonesia in addition to having the main duties, functions and powers, as a good organization and strong has code as orderly operational norm. The rules of conduct in the form of disciplinary rules and codes of conduct. Police agencies have rules are rules about discipline as the honor of being closely related to credibility, commitment and discipline of Polri members. In this case the credibility and commitment of the members of the state police republic of Indonesia is a state official who was given the task and authority as protector and Public Servants, law enforcement and security custodian. ${ }^{2}$

Here there is a change which is essential, which is no longer the Military Police and the status of civilians. Changing Police as a civilian, then as a logical consequence that members of the Police and apply subject to civil law. There has been a change in the value and status for members of the police, the law enacted the same with civil society.

Consequently, the unlawful act within the law or the Police disciplinary code violations, internal institutional settlement, through a disciplinary hearing and the hearing of the Commission of Police Professional Code of Conduct, as stipulated in

\footnotetext{
${ }^{1}$ Student of Master of Law, Universitas Islam Sultan Agung Semarang and Police Member Officer of Cirebon email dikoreinol@gmail.com

2 Pudi Rahardi 2007 Hukum Kepolisian (Profesionalisme dan Reformasi Polri) Surabaya: Laksbang Mediatama p.19.
} 
Government Regulation No. 2 of 2003 on the Police Disciplinary Regulations for Members.

The enactment of Government Regulation No. 3 of 2003 on the Implementation of the Institutional Technical General Court for members of the Police, the examination for police officers in criminal cases ranging stages of the investigation until the trial based on the provisions of Act No 8 of 1981 on Criminal Procedure.

Government Regulation No. 3 of 2003 which substantially, investigations against members of the police who committed the crime committed by the investigators referred prosecute criminal procedural law applicable general judicial environment. In addition to members of the police was also subject to the laws of discipline and code of ethics of Police prevailing in the police organization, so it is possible the imposition of double punishment for police officers who commit criminal acts, which receive criminal sanctions (imprisonment) is also under penalty of discipline as Government Regulation No. 2 of 2003 on the Police Disciplinary Regulations Member. ${ }^{3}$

Thought above, in accordance with Article 11 (3) the Constitution of the Republic of Indonesia Of 1945. Article 27 (1) Constitution of the Republic of Indonesia Of 1945 confirmed the existence of equality before the law and government, and government must uphold the law with no exceptions.

Law enforcement is the process undertaken in an attempt to upholding the legal norms significantly as a code of conduct in public life and state are at least three important elements that affect the performance of law enforcement, among others ${ }^{4}$ :

- Law enforcement institutions, including the infrastructure that supports and mechanisms or working procedures that apply in these institutions.

- The work culture of law enforcement officers, including welfare.

- Regulations that support the performance of law enforcement agencies, both material law and procedural law.

The rule of law itself can only be achieved if the law were to be enforced reflects the values of justice in the society. In other words, in the framework of the rule of law is also necessary to reform or creation of new regulations. ${ }^{5}$

For the sake of the implementation of good law enforcement, the necessary apparatus clean of actions against the law. Therefore, every member of the Police must act and behave in accordance Police Professional Code of Conduct. In the Code of Professional Ethics of Police, one of which stipulates that every member of the Police shall refrain from reprehensible actions and attitudes as well as pioneered every action to overcome the difficulties surrounding communities. In addition, every member of the Police is also expected to refrain from acts of abuse of authority. ${ }^{6}$ Police Professional Code of Conduct contains the translation of the code of conduct each member of the police in dealing with the public, both when performing Reviews

\footnotetext{
${ }^{3}$ Ibid.

${ }^{4}$ StatusHukum 14Juni2012: PenegakHukum inhttp: //statushukum.com/penegakan-hukum.html Accessed on Tuesday October 292013 08: 2

${ }^{5}$ Ibid p. 2

${ }^{6}$ Noah 5Muhammad 2011 Etika Profesi Hukum Bandung: Pusaka Setia p. 144.
} 
their duties and responsibilities and when not on duty and authority among the people. $^{7}$

Writers who work in the field of Legal Aid in polres Cirebon who was handling the case of members of the police who abused drug type of methamphetamine and has been disconnected court of Cirebon. With an excerpt of Decision No. 394 / Pid.Sus. / 2016 / PN Sbr defendant Polres Cirebon members.

The norms contained in the Police Professional Code of Conduct Formulated in the Police Regulation No.Pol: 14 in 2011 have binding force and moral values are high. Violations of the code of ethics of Police then for police officers settling Disputes Relating to breach of discipline and code of conduct, there are legal issues, among others: Decision Session of Discipline and Assembly Code of Conduct is not binding and not final. Because the final decision on the imposition of the law lies in the boss right to punish so that the court decision was limited to only give recommendations to Ankum on the decision handed down based on the legal facts revealed in the hearings.

In order for the study was not out of the subject has been the author set, as well as to avoid any confusion, the authors set boundaries for this study, namely on the Police Professional Code of Conduct Violations in polres Cirebon who was handling the case of members of the police who abused drugs kind shabu- methamphetamine and has been disconnected court of Cirebon.

There are several problems that want authors examined in this study, as follows: 1. How is the Criminal Law Enforcement Against Members of the Police Conducting Crime Narcotics Abuse? 2. How does the Code Enforcement Police Abuse Against Members of the Police?

\section{Results and Discussion}

\subsection{Criminal Law Enforcement Against Members of the Police are performing Criminal Abuse of Narcotics}

Based on the results of the study, researchers study the law enforcement process the crime of drug abuse committed by members of the police identified as Brigadier members of the police Astanajapura that case the crime is already on trial in the District Court Of Sumber, and first underwent Court Hearing that in September, 2017, and after undergoing four times the hearing, the judge finally decided, with an excerpt of Decision No. 394 / Pid.Sus / 2017 / PN.Sbr. October 19, 2017, that the person concerned is declared proven legally and convincingly guilty of committing the crime of "Abuse of Narcotics Group I For Yourself" and sentenced to a prison Criminal Penalties for 6 (six) months.

\subsubsection{Stage Research and Investigation}

The investigation in the legislation of Article 1 paragraph 5 of the Criminal Procedure Code. ${ }^{8}$ Bripka Ato Haryanto et all. stated that the investigation conducted because

\footnotetext{
${ }^{7}$ Moslem Ibnu 2012 Penerapan Bantuan Hukum di Indonesia.

${ }^{8}$ http://id.wikipedia.org/wiki/Divisi_Profesi_dan_Pengamanan_Polri
} 
there was initially no information from the public that at the Green Hill there is one room that is often used as a place to perform Narcotics abuse methamphetamine types, so that the witness and colleagues conducted an investigation.

Lidik results obtained from the info that Brigadier S often come to Hotel Green Hill. ${ }^{9}$ Furthermore Bripka Ato Haryanto et all in the process of law enforcement against drug abuse committed by members of the police in the investigation process applied to a series of actions as follows:

- Arrest; The arrest of the suspects carried out in the interests of an investigation process, as described in Article 16 of the Criminal Procedure Code. ${ }^{10}$ Bripka Ato Haryanto et al justify been arresting $S$ members of the Police Astana Japura Polres Cirebon, as found in possession, control and carry Narcotics types of methamphetamine, the arrests were made on Tuesday, July 4, 2017 about 16:00 pm, in front of Hotel Green Hill village Pasindangan Gunungjati sub-district of Cirebon. ${ }^{11}$

- Detention; According to the provisions contained in Article 1 point 21, the Criminal Procedure Code. ${ }^{12}$ Bripka Ato Haryanto stating that detention of the suspect criminal acts of drug abuse in the interests of further investigation on the case is suspected to him and that the suspect did not flee or destroy evidence. ${ }^{13}$

- Seizure; Article 1 point 16, the Criminal Procedure Code. ${ }^{14}$ The process of seizure of evidence, investigators confiscated spontaneously it Bripka Ato Haryanto and colleagues immediately ambushed and securing Brigadier $S$ in front of the Hotel Green Hill and when searched turned out of a pants pocket Brigadier $\mathrm{S}$ found a Carger HP, and in Carger HP therein contain one (1) package of methamphetamine, then brought Brigadier $\mathrm{S}$ to his house to find his house ransacked lainnya.Setelah evidence turned out under their beds found methamphetamine suction devices such as Bonk. Caused suspect who has been investigated prior to his arrest occurs directly or caught in the act, then the investigator in foreclosure does not include a license from the local state court, but after the seizure of evidence later investigators report to the General Reof Sumber District of Cirebon. ${ }^{15}$

- Examination of witnesses; The process of examination of witnesses, contained in Article 1 point (26) and (27) the Criminal Procedure Code. ${ }^{16}$ Bripka Ato Haryanto and friends - comrades justify all the statements of witnesses recorded in the minutes of the examination of witnesses and signed by witnesses to substantiate the validity of the witness testimony. ${ }^{17}$

- Matered Investigation; In Article 1, point 28, the Criminal Procedure Code. ${ }^{18}$

\footnotetext{
${ }^{9}$ Investigator unit of Polres Cirebon Persoonal Interview Cirebon July 212018 at 11: 45WIB.

${ }^{10}$ http://id.wikipedia.org/wiki/Divisi_Profesi_dan_Pengamanan_Polri10Brigadir Ato Haryanto

${ }^{11}$ Investigator unit of Polres Cirebon July $21 \overline{2018}$ at 11: 45WIB.

12 Op.cit.

${ }^{13}$ Op.cit.

${ }^{14}$ http://id.wikipedia.org/wiki/Divisi_Profesi_dan_Pengamanan_Polri

${ }^{15}$ Loc.cit.

${ }^{16}$ http://id.wikipedia.org/wiki/Divisi_Profesi_dan_Pengamanan_Polri

${ }^{17}$ Loc. Cit.

${ }^{18}$ Op. Cit.
} 
Investigators in the crime of drug abuse committed by police officers, Bripka Ato Haryanto said that investigators submit the evidence is suspected as drug and urine suspects to the Central Forensic Laboratory of the Police Criminal Investigation and the results of tests carried out by requesting assistance to Labkesda Cirebon to do Urine test against Brigadier $S$, and after the test results are positive amphetamine. $^{19}$

- Examination of the suspect; Description indispensable suspect in the investigation process in order to uncover cases related to the crime of drug abuse. Article 189 paragraph 2 of the Criminal Procedure Code. ${ }^{20}$ Bripka Ato Haryanto explained that the inspections narcotics criminal acts committed by members of the police. explained that the suspect admitted that Narcotics types of methamphetamine. The goods obtained from " $A$ " who claim to be Jakarta had known at the time of the evening entertainment at the Pub and Resto Mithas, the purchase system in a way that message through HP outboard to " $A$ " afterwards Brigadier S transfer money to " $A$ ", thereafter money transferred later " $A$ " methamphetamine store it somewhere and then send a text whose contents signpost to take the methamphetamine.

- The results of investigations by the police; Submission of the results of the investigations carried out by two stages, as set out in Article 8 point 3 of the Criminal Procedure Code. ${ }^{21}$ Furthermore Bripka Ato Haryanto stated that the surrender suspects to the Public Prosecutor during the investigation process has been considered completed by the investigator or after the prosecution stated that the investigations are complete. ${ }^{22}$

\subsubsection{Phase Prosecution}

Definition of prosecution set forth in Article 1 paragraph 3 of Act No 16 of 2004 on the Prosecutor of the Republic of Indonesia. ${ }^{23}$ The Public Prosecution charged the defendant with alternative charges, namely Article 112 paragraph (1) Jo RI Article 127 of Act No. 35 of 2009 on Narcotics. In give these demands, the prosecutor does not see that he was a police officer, all processes are the same as in the general public, even his demands could be more severe because the defendant is considered as law enforcement officers are supposed to be more aware of the prohibition of abuse of narcotics, but the defendant intentionally does the crime of drug abuse.

\subsubsection{Settlement Case on Trial}

Stage examination at court level, hearing criminal suspects abuse of narcotic processed inspection using ordinary event.

Furthermore, the judge who examined the case of the crime of drug abuse committed by members of the police stated that the proceedings against the suspect all the proceedings, the trial process and the members involved in the proceedings are all the

\footnotetext{
${ }^{19}$ Loc. Cit.

${ }^{20}$ http://id.wikipedi

${ }^{21} \mathrm{lbid}$

${ }^{22}$ Op. Cit.

23 Alfitral Hapusnya Hak Menuntut dan Menjalankan Pidana Penebar Swadaya Group Jakarta 2012 p.123.
} 
same as when the defendant the general public, on the whole all the process is the same even if he was a member police in the eyes of the law all the same, there is no specificity in prosese examination. Imposition verdict against the defendant was sentenced to suspect with Article 112 paragraph (1) Jo RI Article 127 of Act No. 35 of 2009 on Narcotics, that the person concerned is declared proven legally and convincingly guilty of committing the crime of "Abuse of Narcotics Group I For Yourself "Criminal punishment and sentenced to prison for six (6) months.

\subsection{Enforcement Code of Ethics Police Abuse Against Members of the Police.}

\subsubsection{As an Actor Crime Narcotics Abuse}

In order to achieve legal justice in any violation of the Code of Professional Police conducted objectively and uphold justice and with regard to services the police members who violated the code of ethics of the national police and how many connected the legal problems that snare.

Article 17 paragraph 1 of the Regulation No. 14 of 2011 on the Police Professional Code of Conduct, which has the right to enforce the code of ethics Police are:

- Propam Police

- The Commission code of professional conduct

- The Commission appeals

- Development of legal functions of Police

- HR Police

- Police Propram field of rehabilitation

Members of the police who committed the crime will be dishonorably discharged as specified in the Police Regulation No. 14 of 2011 on the Code of Professional Police Government Regulation No. 1 of 2003 on Termination of Police, Government Regulation No. 3 of 2003 on the Disciplinary Code Members of the Police of the Republic of Indonesia and the Law of the Republic of Indonesia Number 43 Of 1999 on the Amendment of Act No. 8 of 1974 On the Fundamentals of Human Reof Sumber.

The above are some of the rules relating to the enforcement of the code of ethics police, making it clear that the police fortify its members to not break through ethics, so that they can be an example or figure shelter for the community, where members of the police do not keep the ethics of their profession then ruined the image of the police.

Meanwhile, according to Lewis as a member Provost Aiptu who served in Polres Cirebon that in criminal cases involving the abuse of narcotic one member of the police officer in charge of Polres Cirebon region, there are only one case. The first stage of the enforcement process is done entirely through the civil court process pemeriksaanyapun performed by authorized investigators to conduct examination of criminal cases of drug abuse. Once the defendant serving prison time in the public courts for $2 / 3$ of the time served, then the suspect did attempt parole. During the parole defendant summoned by the police for further examined to implement the code of conduct hearing. ${ }^{24}$

\footnotetext{
${ }^{24}$ Aiptu Sugianto Provos Polres Cirebon Personel Interview Cirebon July 252018 at 10: 00WIB.
} 
As for the Provos to give time for 6 months after the defendant is free from the time the penitentiary administration aimed to conduct an investigation, determining the schedule of the trial, did his case and within 6 months of the defendant continues to be monitored its development for future consideration in decisions violations of the code of conduct.

Based on the results of research by the author, that the code of professional conduct enforcement proceedings against members of the police who committed the crime of abuse of drugs, until now the suspect has not been prosecuted. The reason is that the suspect be given time to improve himself and for supervision in advance. It can be said that in the process of enforcement of the code of ethics of the national police who committed the crime of abuse of narcotics in the execution of the investigation is not in accordance with the legislation in force, the implementation of a Provost still use the policy of the police chief who did not immediately hold a session code of ethics of the convict first defendant but waiting for the execution of criminal penalties was completed recently conducted a trial code of conduct.

\section{Closing}

\subsection{Conclusion}

- Law enforcement process against members of the police who caught the crime of drug abuse cases are in accordance with the legislation in force.

- Police enforcement of code violations against members of the police committed the crime of abuse of drugs applicable to all the same in the eyes of the law, even in law enforcement that the suspect was a police officer can impose more severe criminal. The code of professional conduct enforcement proceedings against members of the police who police caught the criminal case of drug abuse is still not implemented as much as possible where the police did not immediately crack down on members who caught the criminal case due to the substance abuse policy that is where the police chief Police officers Still Very Less Personnel.

\subsection{Suggestion}

- For the police should be able to monitor its members and more law-abiding inculcate higher so that its members can avoid the crime of drug abuse.

- For the judge should in decisions against criminal suspects abuse of drugs used for himself, the judge should have the courage in decisions rehabilitation for drug addiction just as a disease that must be cured by medical means and not with criminal penalties such as imprisonment.

\section{Bibliography}

[1] Act No 16 of 2004 on the Prosecutor of the Republic of Indonesia

[2] Act No 2 of 2002 on the Indonesian National Police.

[3] Act No.35 Of 2009 on Narcotics.

[4] Government Regulation No. 1 of 2003 on Termination of Police. 
[5] Government Regulation No. 2 of 2003 on Discipline Regulations Members of Indonesian National Police.

[6] Government Regulation No. 3 of 2003 on the Implementation of the Institutional Technical General Court for members of the Police

[7] Hartono, Penyidikan dan Penegakan Hukum Pidana, Jakarta: Sinar Grafika, 2010.

[8] http://id.wikipedia.org/wiki/Divisi_Profesi_dan_Pengamanan_Polri

[9] Legal status: Law Enforcement, in http: // statushukum.com / enforcementhukum.html.

[10] Moslem Ibnu 2012 Penerapan Bantuan Hukum di Indonesia.

[11] Muhamad Rusli 2011 Sistem Peradilan Pidana Indonesia, Yogyakarta: UII Pres Yogyakarta.

[12] Muhammad Nuh 2011 Etika Profesi Hukum Bandung: Pusaka Setia.

[13] Police Regulation No. 14 of 2011 on the Police Professional Code of Conduct

[14] Police Regulation No.Pol: 14 in 2011.

[15] Pudi Rahardi 2007 Hukum Kepolisian (Profesionalisme dan Reformasi Polri) Surabaya: Laksbang Mediatama.

[16] The Code of Criminal Procedure 